\title{
Holocene evolution and sedimentation rate of Alikes Lagoon, Zakynthos island, Western Greece - preliminary results
}

\section{P. Avramidis ${ }^{1}$ and N. Kontopoulos ${ }^{2}$}

${ }^{1}$ Technological Educational Institute of Mesolonghi, Department of Aquaculture and Fisheries Management, 30200 Mesolonghi, Greece

${ }^{2}$ University of Patras, Department of Geology, 26500 Patras, Greece

Received: 12 December 2008 - Accepted: 3 March 2009 - Published: 24 March 2009

Correspondence to: P. Avramidis (pavramid@teimes.gr)

Published by Copernicus Publications on behalf of the European Geosciences Union.

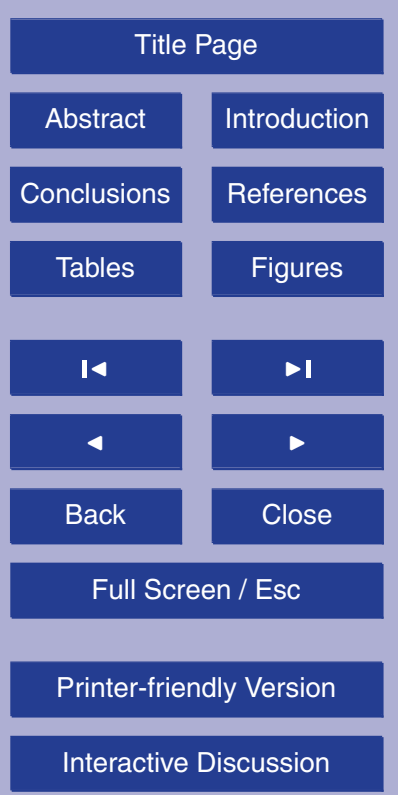

Holocene evolution

of Alikes lagoon

P. Avramidis and

N. Kontopoulos

\section{Title Page}

\section{Abstract}

troduction

Conclusions

Tables

Figures

14

4

Back

Close

\section{Full Screen / Esc}

Printer-friendly Version

Interactive Discussion

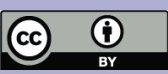




\section{Abstract}

In the present study we present preliminary results of Zakynthos Alikes lagoon, which is one of the most seismically active regions of Greece. In order to estimate - interpret the Holocene evolution of the area and to reconstruct the palaeonvironmental 5 changes, we based on the data of a $21 \mathrm{~m}$ sediment core. Sediment types, structure, colour, as well as contact depths and bed characteristics, were recorded in the field. Standarised sedimentological analysis were carried out, on 46 samples including grain size analysis, calculation of moment measures, and micro- and molluscan fossils of 17 selected samples. Moreover, radiocarbon age determinations have been made on 10 individual Cardium shells from two horizons and whole - core Magnetic Susceptibility (MS) measurements were taken. The interpretation of depositional environments suggests a coastal environment (restricted-shallow) with reduced salinity such as a lagoon margin and in a tidal flat and/or marsh particularly. The maximum age of the study sediments is about $8500 \mathrm{BP}$. The rate of sedimentation between $8280 \mathrm{BP}$ and $5590 \mathrm{BP}$ 15 was $5.3 \mathrm{~mm} / \mathrm{yr}$ and between $5590 \mathrm{BP}$ and modern times $1.03 \mathrm{~mm} / \mathrm{yr}$. The rate of sedimentation was higher until mid-Holocene while decrease after to $1.03 \mathrm{~mm} / \mathrm{yr}$, results which are similar to other coastal areas of western Greece.

\section{Introduction}

Studies related to coastal sedimentological environments, allow the recognition of coastline changes and give information about the rate of sedimentation, eustatic sea level changes and tectonic movements. Such as environments which can record these environmental changes and associate them with tectonic activity, variations in water and sediment yield, are the lagoon - lagoonal areas (Bird, 1985). Different approaches have been taken to reconstruct the Holocene coastal - lagoon environmental changes basen on geological, geochronological and sedimentological methods. Similar studies in western Greece, investigating and reviewing the Holocene environmental changes
4, 55-75, 2009

Holocene evolution

of Alikes lagoon

P. Avramidis and

N. Kontopoulos
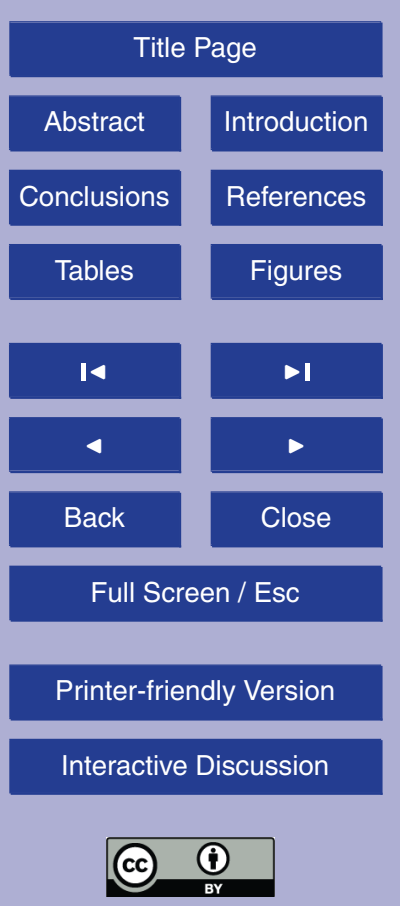
in coastal lagoonal areas, have been carried out by Kontopoulos and Avramidis (2003), Kraft et al. (2005), Vött (2007), Avramidis et al. (2008) and Kontopoulos and Koutsios (2009).

In this study we present preliminary results of Zakynthos Alikes wetland - lagoon, 5 concerning the Holocene palaeonvironmental evolution - changes of the area, based on a $21.2 \mathrm{~m}$ sediment core, GA-1.

\section{Geological and tectonic setting}

The study area is the Alikes wetland (an old salt pan) which is located on the nothern part of Zakynthos island, the sixth of the Ionian islands, and expand in an area of $10400000 \mathrm{~m}^{2}$ (Figs. 1, 2 and 3). The Ionian islands of western Greece form part of the para-autochthonous Apulian foreland of the Hellenide orogen and include rocks of the Pre-Apulian (or Paxos) and Ionian isopic zones (= terranes) (Underhill, 1989). Zakynthos island is characterised by two geotectonic zones the Pre-Apulian and the Ionian zone (Aubouin and Dercourt, 1962). It is located near the nothern terminus of 15 the Hellenic Trench (Fig. 1), very close to the convergent boundary between the African and European plate and the diapirism area of the evaporites, that belong to the Alpine basement.

The area is one of the most seismically active regions in Europe and neotectonic fault zones display mainly a NNW-SSE trending faults (Lekkas, 1993), while the sedimentological evolution of the island was influenced by compresional and extensional tectonics (Zelilidis et al., 1998). Sedimentation in Zakynthos island can be distinguished in carbonates Cretaceous to Miocene and clastic Plio - Quaternary (Fig. 2).

In the study area during the last decades human activities such as agriculture, irrigation works and building development influenced, the water surface of the lagoon. On the northwest side, the Alikes lagoon is separated from the Ionian Sea by a low relief sand barier and has limited communication with the open sea with a sort and narrow inlet (Fig. 4). The maximum water depth of the lagoon is up to $45 \mathrm{~cm}$ and an average depth only up to $15 \mathrm{~cm}$ (Fig. 5).

$4,55-75,2009$

Holocene evolution

of Alikes lagoon

P. Avramidis and

N. Kontopoulos
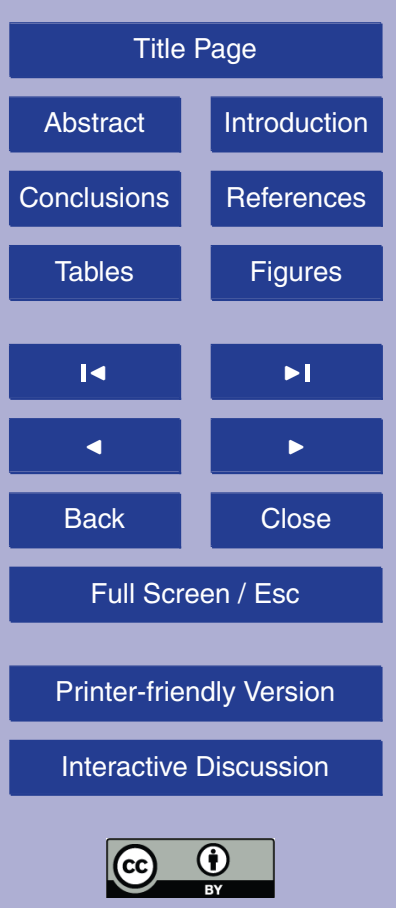


\section{Method}

The exploratory core GA-1 was bored by the Technological Educational Institute of Mesolonghi and the University of Patras, in February 2008, at the geographical posistion $\mathrm{N} 37^{\circ} 50^{\prime} 32^{\prime \prime}, \mathrm{E} 20^{\circ} 45^{\prime} 51^{\prime \prime}$ (Fig. 3). The drilling equipment used was a rotation

5 Longyear 38, with single tube core barrel with tungsten carbide bit and $101 \mathrm{~mm}$ diameter.

All the segments of the core were sealed with cling film. Sediment types, structure, colour, as well as contact depths and bed characteristics, were recorded. Colour were identified using a Minolta CM-2002 hand held spectrophotometer.

10 Standarised sedimentological analysis were carried out, on 46 samples including particle size analysis, calculation of moment measures, such as mean, sorting, kurtosis and skewness. Particle size distribution was made using a Malvern Mastersizer 2000, while moment measures were calculated using GRADISTAT V.4 and based on Folk (1974) nomenclature. Moreover micro- and molluscan fossils of 17 selected samples 15 were examined.

Whole - core Magnetic Susceptibility (MS) measurements were taken using a Bartington MS2 magnetic susceptibility meter with MS2-F probe type. Radiocarbon age determinations have been made on individual Cardium shells from two horizons, and results such as Conventional Radiocarbon Age and Two - Sigma calendar calibration were taken. Radiocarbon analysis was carried out in Beta Analystic Labs.

\section{Results}

\subsection{Core description}

Most of the observed sedimentary units, are composed of fine material, fine to coarse silt and a few coarser intercalations of fine to medium sand (Fig. 6).

$4,55-75,2009$

Holocene evolution

of Alikes lagoon

P. Avramidis and

N. Kontopoulos

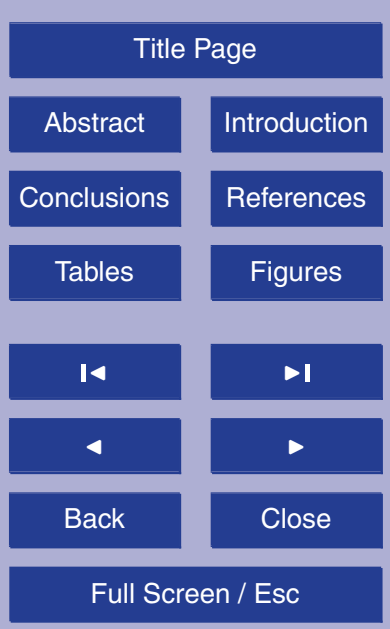

Printer-friendly Version

Interactive Discussion 
We recognised three main sedimentary units the upper UI (3.00-7.50 m), middle UII (7.50-16.80 m) and lower UIII (16.80-21.20 m) (Fig. 6).

Unit I: refer to the upper part of the core segment between depth $3.00 \mathrm{~m}$ to $7.50 \mathrm{~m}$ (Fig. 6). We didn't take into account material between depths $0.00-3.00 \mathrm{~m}$ as it is 5 classified as filling material (pave) for road construction. The unit consist of poorly to very poorly sorted, grayish olive, laminated fine to medium silt, rich in organic matter with bioturbation structures and shell fragments. Silt is intercalated by three main horizons of poorly sorted, olive brown to dark olive, fine to medium sand (5.00-5.22 m, $6.00-7.00 \mathrm{~m}$ and $7.25-7.50 \mathrm{~m}$ ). Contacts between silt and sand are characterised as 10 slightly erosional. The sand fraction consists of foraminifera, ostracodes and mollusks in proportion less than $2 \%$ to the clastic grains. Also, there are carbonate - cementing aggregates in abundance in the sand fraction.

Unit II: refer to the middle core segment between depth 7.50-16.80 m (Fig. 6), which consist of poorly sorted, very dark greenish gray fine silt, with shell fragments, thin layers rich in organic matter with plant remains and abundant shell fragments and Cardium shells. The sand fraction contains mostly micro- and macrofossils and abundance plant remains. Caliche-like evaporate, largely of a calcium carbonate type, is found cementing some of the grain together into aggregates. Internally to this unit we distinguish three layers $(8.60-9.00 \mathrm{~m}, 12.40-12.60 \mathrm{~m}$ and $14.65-15.10 \mathrm{~m})$ consisting of poorly sorted grayish olive fine silt and is characterised by ripple lamination.

Unit III: refer to the lower core segment between depth 16.80-21.20 m (Fig. 6), which consist of poorly sorted, greenish gray fine to coarse silt. This unit is characterized by the presence of Cardium, Cerithium and Hydrobia, Ammonia shells and abundant organic matter. Also, there are carbonate-cementing aggregates in abundance in the sand fraction.

In the lower part of the unit we observe an increase in sand participation and we distinguish a layer of poorly sorted, light olive gray to grayish olive, coarse silt.
$4,55-75,2009$

\section{Holocene evolution}

of Alikes lagoon

P. Avramidis and

N. Kontopoulos

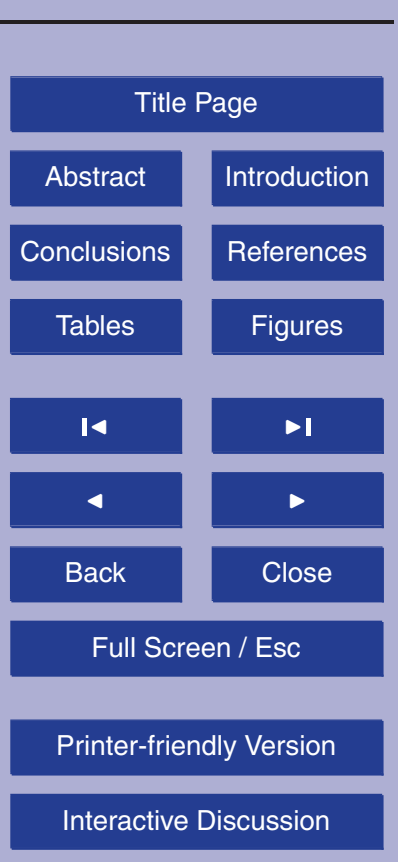

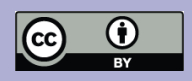


The distribution of particles throughout the core indicate a relative uniform distribution of grain size. Sediment types are fine to coarse silt (Fig. 7) with three intercalations of medium sand in the upper unit UI. The presence of sand is low, ranging between 0 to $55 \%$, clay percent ranges between 2 to $20 \%$ and silt between 69 to $85 \%$ (Fig. 7 ). In the upper core segment UI, the silt material is characterised as poorly to very poorly sorted, with values of $\sigma 1$ range between 1.46 to $2.73 \Phi$ (Fig. 6). Skewness indicate basically a symmetrical distribution and values of kurtosis propose a mesokurtic distribution. Mean values ranges between 6.98 to $7.96 \Phi$ (Fig. 6). The sand layers of the upper unit UI (o be poorly to very poorly sorted ( 011.13 to 2.86$)$ with mean values ranging between 1.86 to $3.83 \Phi$ (Fig. 6). Skewness in all sand samples indicate very fine skewed distribution while kurtosis propose mainly an extremely leptokurtic distribution. The very fine skewed value is caused by the presence of a fine tail in the sand-dominate size frequency curve. This fine tail in combination with the poorly to very poorly sorting 15 and extremely leptokurtic kurtosis may be suggesting an event analogous with a fluvial flood. This event may occur in a coastal environment such as a sandy tidal flood. If this happens then the silt beds of this unit which have a very low sand content, poorly to very poorly sorting and normal distribution, have deposited in a sheltered muddy tidal flat or marshy area.

The grain size analysis in the middle unit UII indicate a uniform distribution of poorly sorted ( $\sigma 11.55$ to 1.98$)$ fine silt, with mean values vary from 6.85 to $7.58 \Phi$. Skewness and kurtosis indicate mainly a symmetrical and mesokurtic distribution, while the participation of sand is very low $<5 \%$ (Fig. 6). These grain size statistical parameters are the same as those of the silt beds of the unit I. This event and the very low sand content suggest also a sheltered muddy tidal flat or marshy area.

The lower unit UIII of the core is characterized by poorly sorted fine to medium silt and the increase of the sand participation in the lower part of UIII, depth 20.55$21.20 \mathrm{~m}$, where we have the presence of coarse silt. Participation of sand is low $<7 \%$
$4,55-75,2009$

Holocene evolution

of Alikes lagoon

P. Avramidis and

N. Kontopoulos
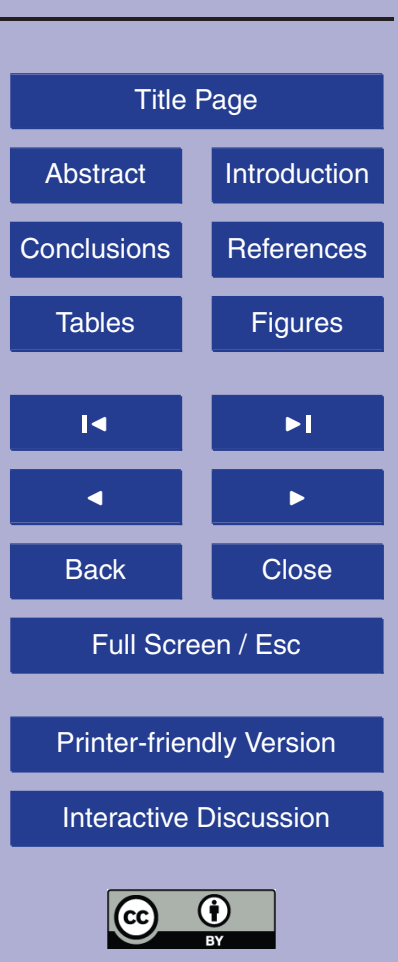
with exception the lower part of UIII where increases up to $23 \%$. Skewness present a symmetrical to fine skewed distribution, while kurtosis a mesokurtic one. The samples from the coarse silt from the lower part of the unit UIII, indicate a platykurtic distribution of grain size (Fig. 6). According to the grain size statistical parameters the mainly 5 part of the unit III has deposited also in a sheltered muddy tidal flat or marshy area. The lower part of the unit III where the sand content increases, the skewness is near symmetrical to fine skewed and the kurtosis is slight platykurtic, may have deposited in a mixed flat environment.

\subsection{Magnetic susceptibility}

10 Magnetic susceptibility values indicate a non uniform distribution between the three core units. Highest readings were observed in the lower core segment UIII reaching 112 C.G.S. units and an average value 45 C.G.S. units (Fig. 6). The middle core section UII indicate a decrease in magnetic susceptibility with maximum values at 79 C.G.S. units and an average of 16 C.G.S. The upper core section UI reach a relative higher average value than UII with highest reading at 77 and an average value of 25 . From the above measurements a clearly differentiation in magnetic susceptibility values can be observed in the lower core segment UIII. The above variations can be related to different sediment sources and local tectonic activity.

\subsection{Radiocarbon dating}

20 The results of radiocarbon analysis for the samples R2 and R20 (Fig. 6) are presented in Table 1. Dates are reported as RCYBP (radiocarbon years before present, present $=A D$ 1950). The conventional radiocarbon age represents the measured radiocarbon age corrected for isotopic fractionation and calculated using the delta 13C. The calendar calibrated results are calculated from the conventional radiocarbon age and
$4,55-75,2009$

\section{Holocene evolution}

of Alikes lagoon

P. Avramidis and

N. Kontopoulos
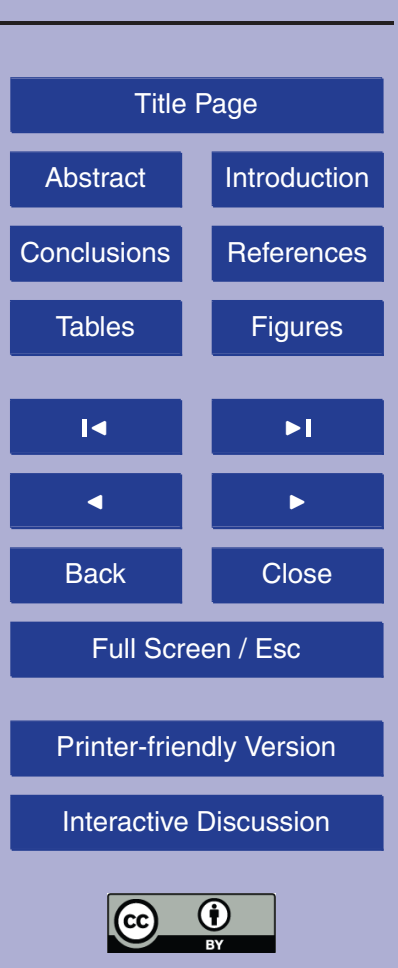


\subsection{Fauna composition}

The faunal composition were examined in 17 samples (M1-M17, Fig. 6) and is represented by poor assemblages of foraminifera, ostracodes and molluscs (Ammonia 5 beccarii, Elphidium crispum, Quinqueloculina seminula, Cyprideis torosa, Cardium edulis Hydrobia (H.) cf. ventrosa) (Fig. 8). This fauna suggests a coastal environment (restricted-shallow) with reduced salinity such as a lagoon margin and in a tidal flat and low marsh particularly.

\section{Discussion and conclusion}

10 Studies related to the rate of sedimentation and relative sea level changes in coastal lagoon sediments in western Greece, have been discussed by Kontopoulos and Avramidis (2002), Kraft et al. (2005), Kelletat (2005), Vött (2007) and Kontopoulos and Koutsios (2009). The above studies correlate the radiocarbon data with the tectonic regime, the sea level changes and with archaeological records. In the present study we reveal two different stages of sedimentation rate: the first one between $8280 \mathrm{BP}$ and $5590 \mathrm{BP}(5.3 \mathrm{~mm} / \mathrm{yr})$ and the second one between $5590 \mathrm{BP}$ and modern times $(1.03 \mathrm{~mm} / \mathrm{yr})$. The above sedimentation rates are similar to previous studies in coastal environments of western Greece and distinguish a difference in relative sea level curve during mid Holocene (5000-6000 cal BP) (Vött, 2008).

The Alikes lagoon are located near the tectonic structure of Volime fault (Fig. 9), which has been recorded with vertical displacement over 100 m (Lekkas, 1993) (Fig. 9). The activity of Volime fault controlled the Holocene evolution and depositional environments of Alikes lagoon and influence the rate of sedimentation. The recorded change of sedimentation rate after mid-Holocene $(5000 \mathrm{BP})$ can be related both to seismotectonic activity of Volime fault and to sea level change. Although local tectonism influ-
4, 55-75, 2009

Holocene evolution

of Alikes lagoon

P. Avramidis and

N. Kontopoulos

\section{Title Page}

Abstract

Introduction

Conclusions

References

Tables

Figures

I

14

$\Delta$

4

$>$

Back

Close

Full Screen / Esc

Printer-friendly Version

Interactive Discussion

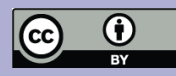


ence the depositional environments and the reconstruction of relative sea level curves, the results of the present study are comparable with the mean relative sea level evolution of northwestern Greece (Vött, 2008) (Fig. 10).

The fauna of the study sediment suggests a coastal environment (restricted-shallow) 5 with reduced salinity such as a lagoon margin and in a tidal flat and/or marsh particularly. The grain size statistics advocate the mentioned environmental determination. The maximum age of the study sediments is about $8500 \mathrm{BP}$, while differences in magnetic susceptibility are related to sediment source area and to the local seismo-tectonic activity.

\section{References}

Aubouin, J. and Dercourt, J.: Zone préapulienne, zone ionienne et zone du Gavrovo en Péloponnèse occidental, Bull. Soc. Gèol. France, 7, t. IV, 785-794, Paris, 1962.

Avramidis, P., Bouzos, D., Antoniou, V., and Kontopoulos, N.: Application of grain size trend analysis and spatio-temporal changes of sedimentation, as a tool for lagoon management. Case study: the Kotychi lagoon (western Greece), Geological Carpathica, 59, 3, 261-268, 2008.

Bird, E.: Coastline changes. A global review, J. Wiley and Sons, Chichester, 219 pp., 1985.

Folk, R. I.: Petrology of sedimentary rocks, Hamphill, Austin, Texas, 1-182, 1974.

Kelletat, A.: Holocene sea level curve for the eastern Mediterranean from multiple indicators, Zeitschrift für Geomorphologie N.F., Supplement 137, 1-9, 2005.

Kontopoulos, N. and Avramidis, P.: A late Holocene record of environmental changes from the Aliki lagoon, Egion, North Peloponnesus, Greece, Quatern. Int., 111, 75-90, 2003.

Kontopoulos, N. and Koutsios, A.: A late Holocene record of environmental changes from Kotihi lagoon, Elis Northwest Peloponnesus, Greece, Quatern. Int., in press, doi:10.1016/j.quaint.2008.10.001, 2009.

Kraft, J. C., Rapp, G. (Rip), Gifford, J. A., and Aschenbrenner, S. E.: Coastal change and archaeological settings in Elis, The American School of Classical Studies at Athens, Hesperia, 74/I, 1-39, 2005.
4, 55-75, 2009

\section{Holocene evolution}

of Alikes lagoon

P. Avramidis and

N. Kontopoulos

\section{Title Page}

Abstract

Introduction

Conclusions

References

Tables

Figures

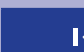

14

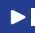

4

Back

Close

Full Screen / Esc

Printer-friendly Version

Interactive Discussion

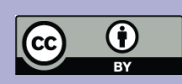


Lekkas, E.: Neotectonic map of Greece, Zakynthos - Volime, scale 1:50000, University of Athens, 116 pp., 1993.

Underhill, J.: Triassic evaporites and Plio-Quaternary diapirism in western Greece, Journal of Geological Society of London 145, 269-282, 1988.

5 Vött, A.: Relative sea level changes and regional tectonic evolution of seven coastal areas ni NW Greece since the mid-Holocene, Quaternary Sci. Rev., 26, 894-919, 2007.

Zelilidis, A., Kontopoulos, N, Avramidis, P., and Piper D. J. W.: Tectonic and sedimentological evolution of the Pliocene - Quaternary basins of Zakynthos, Greece: Case study of the transition from compressional to extensional tectonics, Basin Res., 10(4), 393-408, 1998.
4, 55-75, 2009

\section{Holocene evolution} of Alikes lagoon

P. Avramidis and

N. Kontopoulos

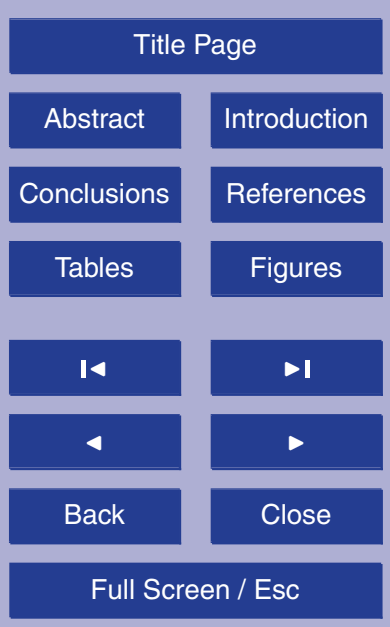

Printer-friendly Version

Interactive Discussion 
4, 55-75, 2009

\section{Holocene evolution of Alikes lagoon}

P. Avramidis and

N. Kontopoulos

Table 1. Radiocarbon dates of shell samples from the studied core.

\begin{tabular}{cccccccc}
\hline Sample & $\begin{array}{c}\text { Depth } \\
(\mathrm{m})\end{array}$ & Material & Analysis & $\begin{array}{c}\text { Measured } \\
\text { Radiocarbon } \\
\text { Age }\end{array}$ & $\begin{array}{c}\text { Conventional } \\
\text { Radiocarbon } \\
\text { Age }\end{array}$ & $\begin{array}{c}\text { 2 Sigma } \\
\text { Calibration }\end{array}$ & $\begin{array}{c}\text { Radiocarbon Age } \\
\text { with } \\
\text { Calibration curve }\end{array}$ \\
\hline R-2 & 5.75 & Cardium Shell & AMS & $4850+/-50 \mathrm{BP}$ & $5250+/-50 \mathrm{BP}$ & 5710 to $5540 \mathrm{BP}$ & $5590 \mathrm{BP}$ \\
$\mathrm{R}-20$ & 20.00 & Cardium Shell & AMS & $7330+/-50 \mathrm{BP}$ & $7790+/-50 \mathrm{BP}$ & 8360 to $8160 \mathrm{BP}$ & $8280 \mathrm{BP}$ \\
\hline
\end{tabular}




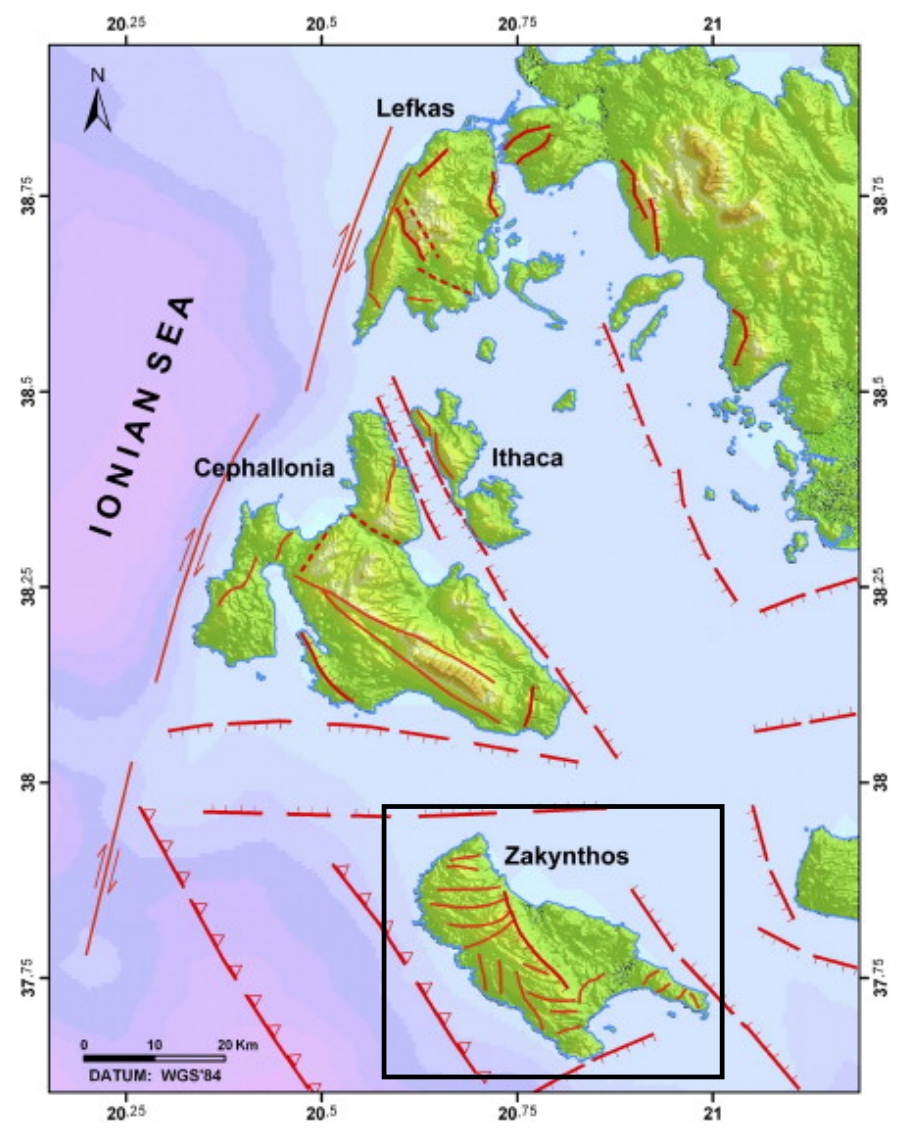

4, 55-75, 2009

\section{Holocene evolution of Alikes lagoon \\ P. Avramidis and \\ N. Kontopoulos}

\begin{tabular}{|c|c|}
\hline \multicolumn{2}{|c|}{ Title Page } \\
\hline Abstract & Introduction \\
\hline Conclusions & References \\
\hline Tables & Figures \\
\hline I4 & \\
\hline 4 & $>$ I \\
\hline Back & Close \\
\hline Full Screen / Esc
\end{tabular}

Printer-friendly Version

Fig. 1. Regional map of the lonian islands. Inserted box shows Zakynthos island.

Interactive Discussion 


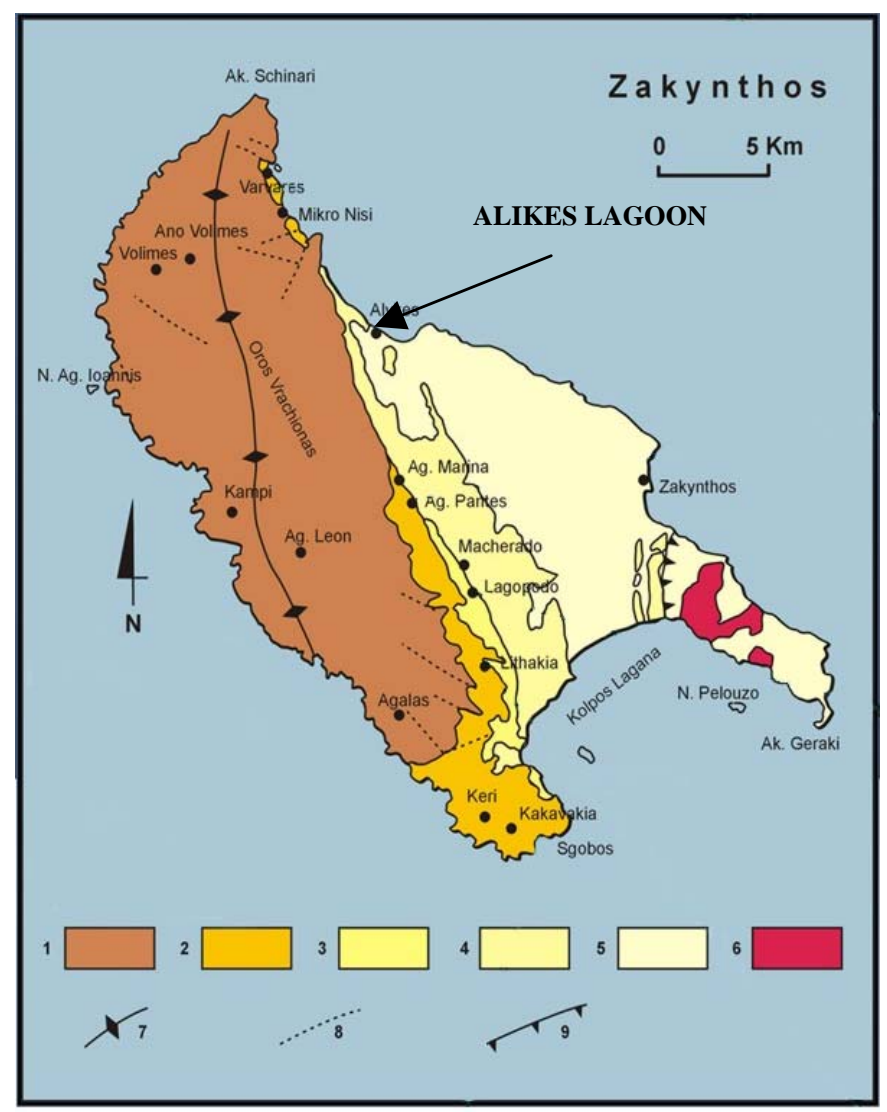

$4,55-75,2009$

\section{Holocene evolution} of Alikes lagoon

P. Avramidis and

N. Kontopoulos

\section{Title Page}

\section{Abstract}

Introduction

Conclusions

References

Tables

Figures
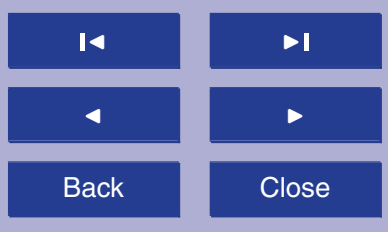

Back

Close

\section{Full Screen / Esc}

Printer-friendly Version

Interactive Discussion Eocene carbonates, 3. Oligocene marly carbonates, 4. Miocene clastics and carbonates, 5 . Pliocene-Quaternary alluvial deposits, 6. Ionian evaporites and breccias, 7. Anticline, 8. Fault, 9. Main thrust. 


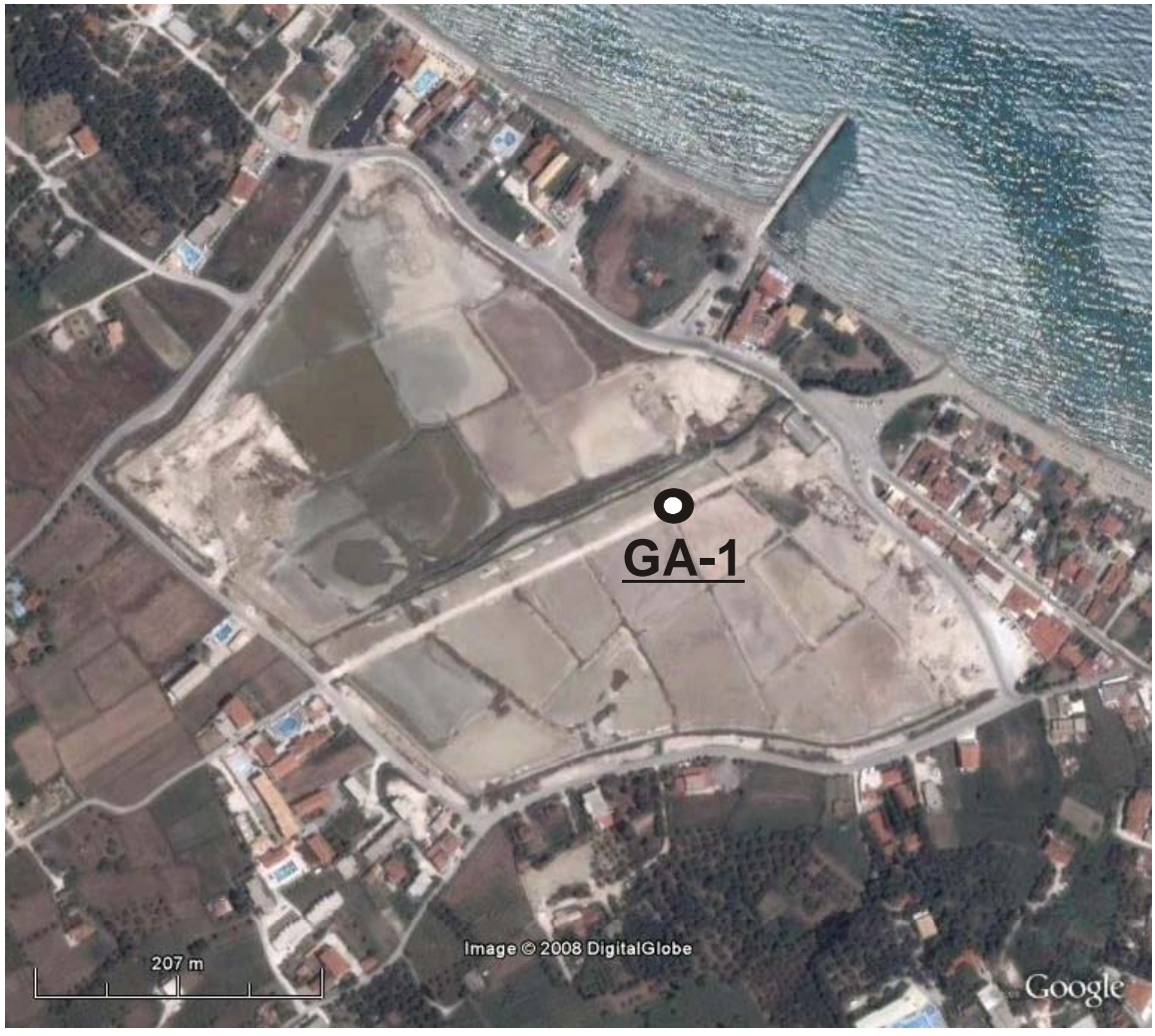

Fig. 3. General view of Alikes lagoon and the location of borehole GA-1.
4, 55-75, 2009

Holocene evolution of Alikes lagoon

P. Avramidis and

N. Kontopoulos

Title Page

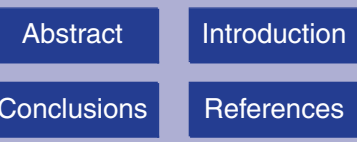

Tables

Figures

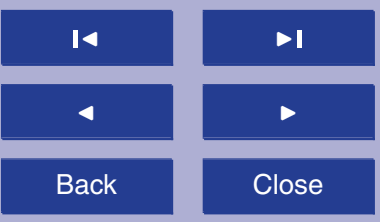

Full Screen / Esc

Printer-friendly Version

Interactive Discussion

(a) (1) 


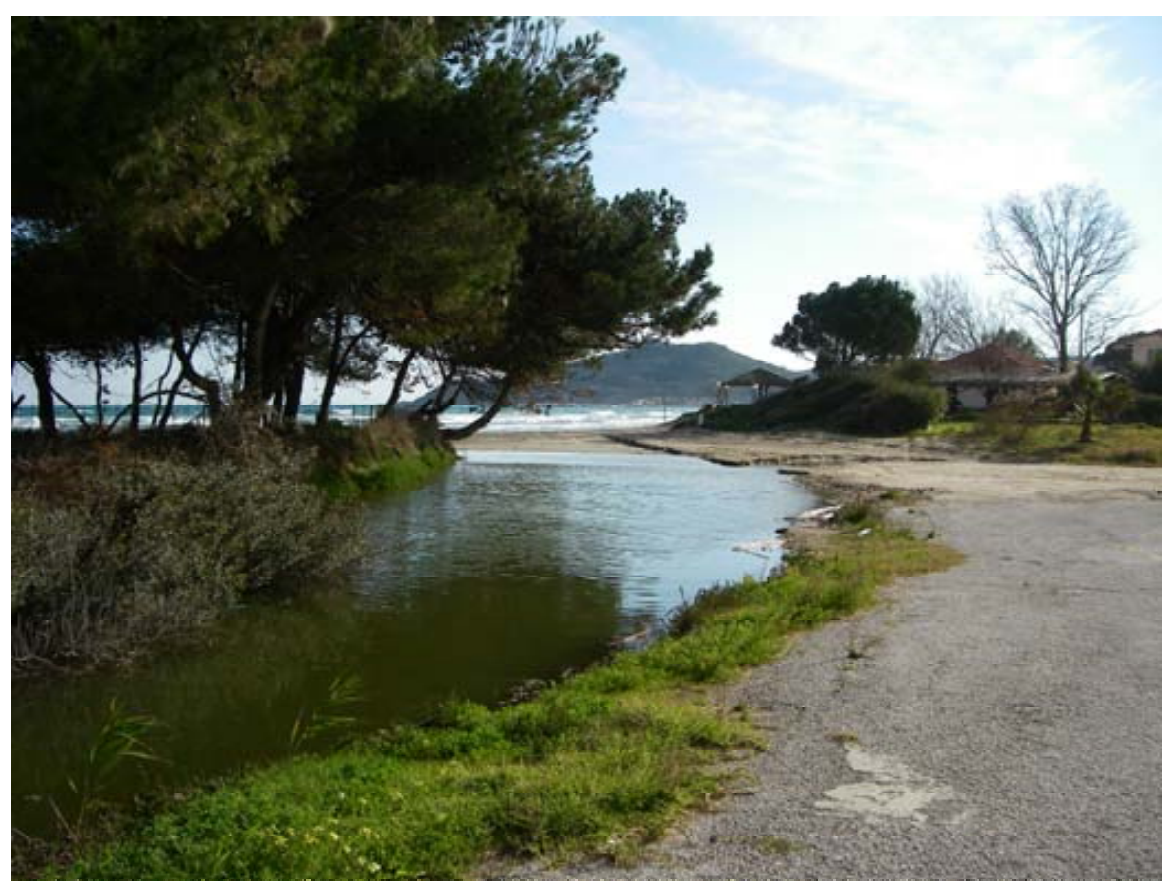

Holocene evolution of Alikes lagoon

P. Avramidis and

N. Kontopoulos

Title Page

\begin{tabular}{c|c} 
Abstract & Introduction \\
\hline Conclusions & References \\
\cline { 2 - 2 } &
\end{tabular}

Tables Figures

14

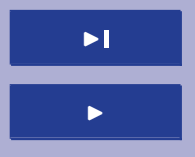

Back

Close

Full Screen / Esc

Fig. 4. The narrow inlet in the northern part of the lagoon.

Printer-friendly Version

Interactive Discussion

() (1) 


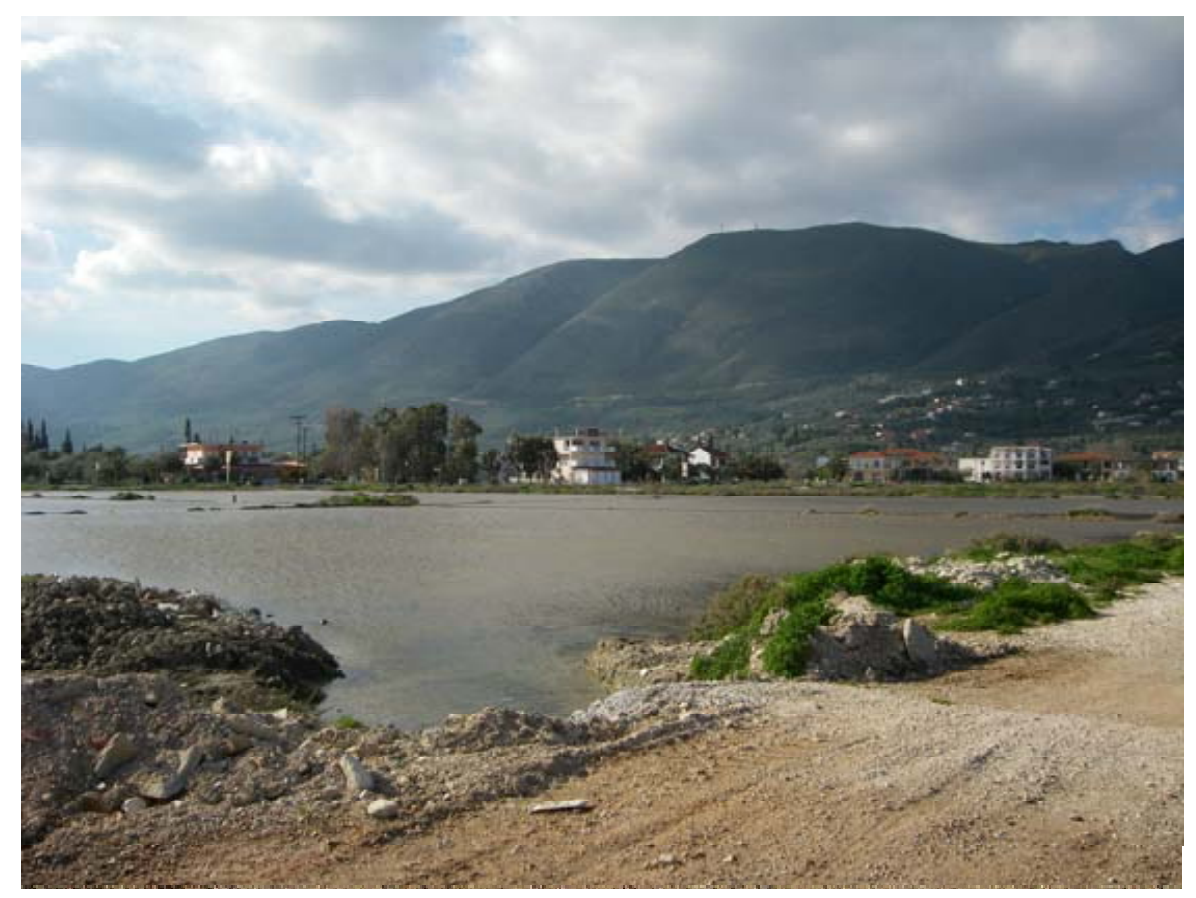

\section{Holocene evolution} of Alikes lagoon

P. Avramidis and

N. Kontopoulos

Title Page

\begin{tabular}{|c|c|}
\hline Abstract & Introduction \\
\hline Conclusions & References \\
\hline Tables & Figures \\
\hline & \\
\hline $\mathbf{1}$ & $-\mathbf{I}$ \\
\hline $\mathbf{4}$ & - \\
\hline Back & Close \\
\hline Full Screen / Esc \\
\hline
\end{tabular}

Fig. 5. General view of the lagoon with maximum depth up to $45 \mathrm{~cm}$.

Printer-friendly Version

Interactive Discussion 


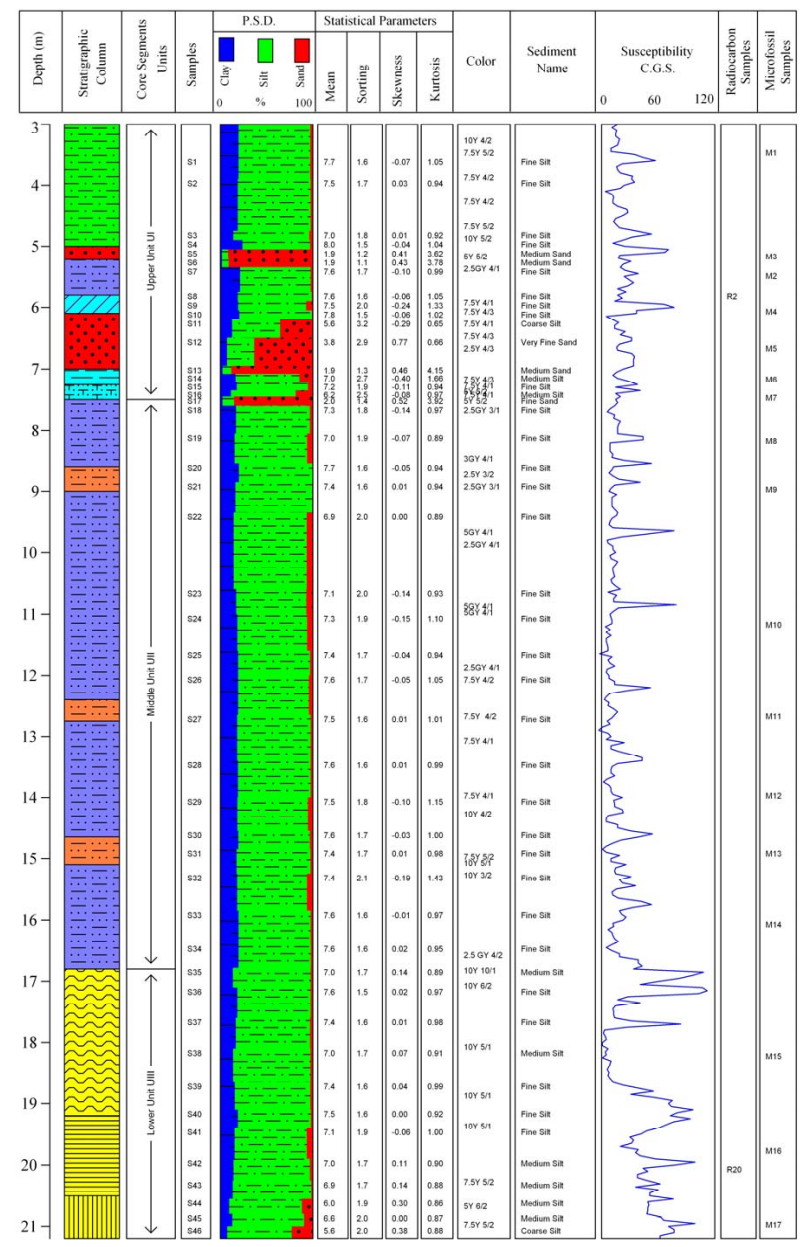

4, 55-75, 2009

Holocene evolution

of Alikes lagoon

P. Avramidis and

N. Kontopoulos

Title Page

Abstract

Conclusions

Tables

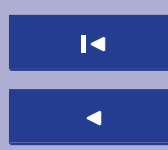

Back

Full Screen / Esc

Printer-friendly Version

Interactive Discussion

Fig. 6. Borehole GA-1 profile, showing the sedimentary units, the grain size distribution, statistical parameters, color, the samples location and the results of magnetic susceptibility.

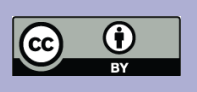


4, 55-75, 2009

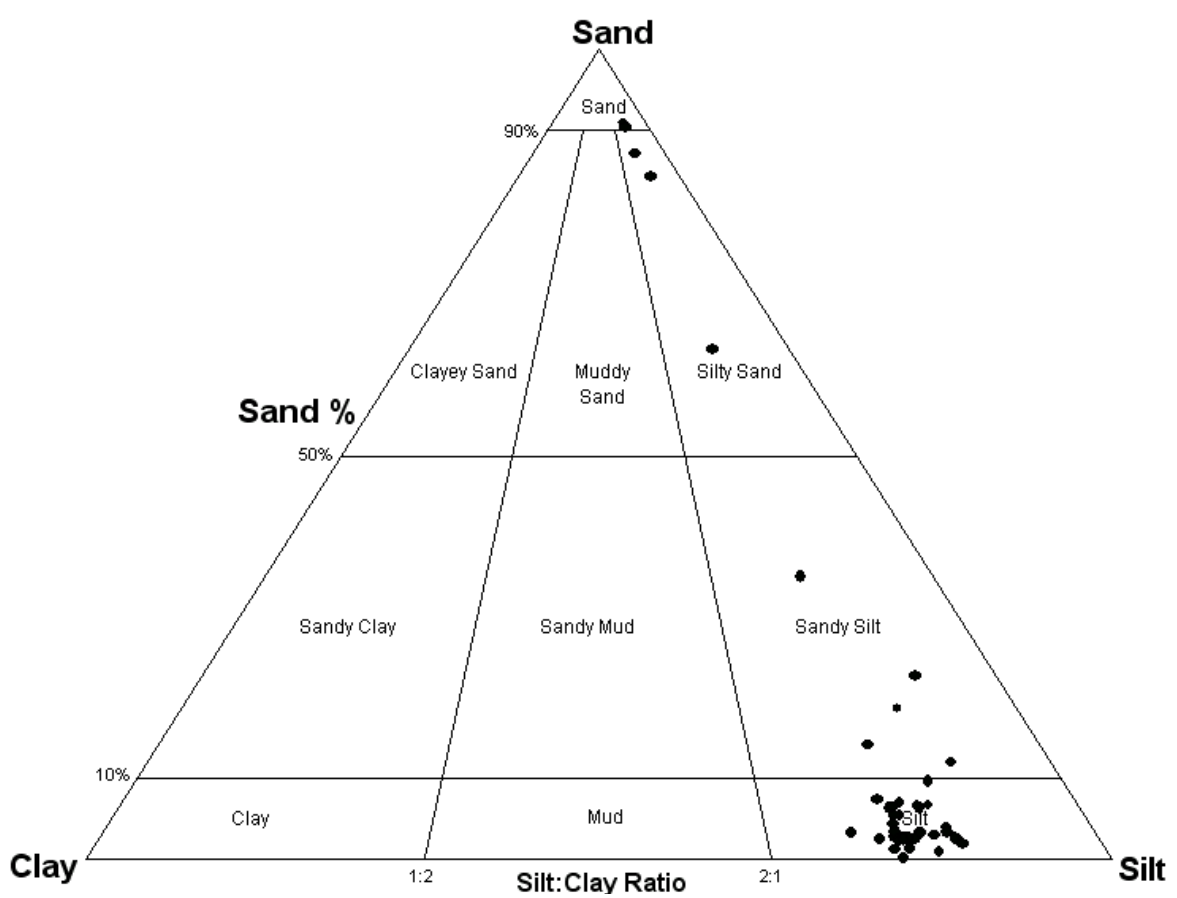

\section{Holocene evolution of Alikes lagoon \\ P. Avramidis and \\ N. Kontopoulos}

\begin{tabular}{|c|c|}
\hline \multicolumn{2}{|c|}{ Title Page } \\
\hline Abstract & Introduction \\
\hline Conclusions & References \\
\hline Tables & Figures \\
\hline & \\
\hline I4 & $\bullet \mathbf{I}$ \\
\hline 4 & $\bullet$ \\
\hline Back & Close \\
\hline Full Screen / Esc
\end{tabular}

Fig. 7. Ternary diagram of sand - silt - clay.

Printer-friendly Version

Interactive Discussion 


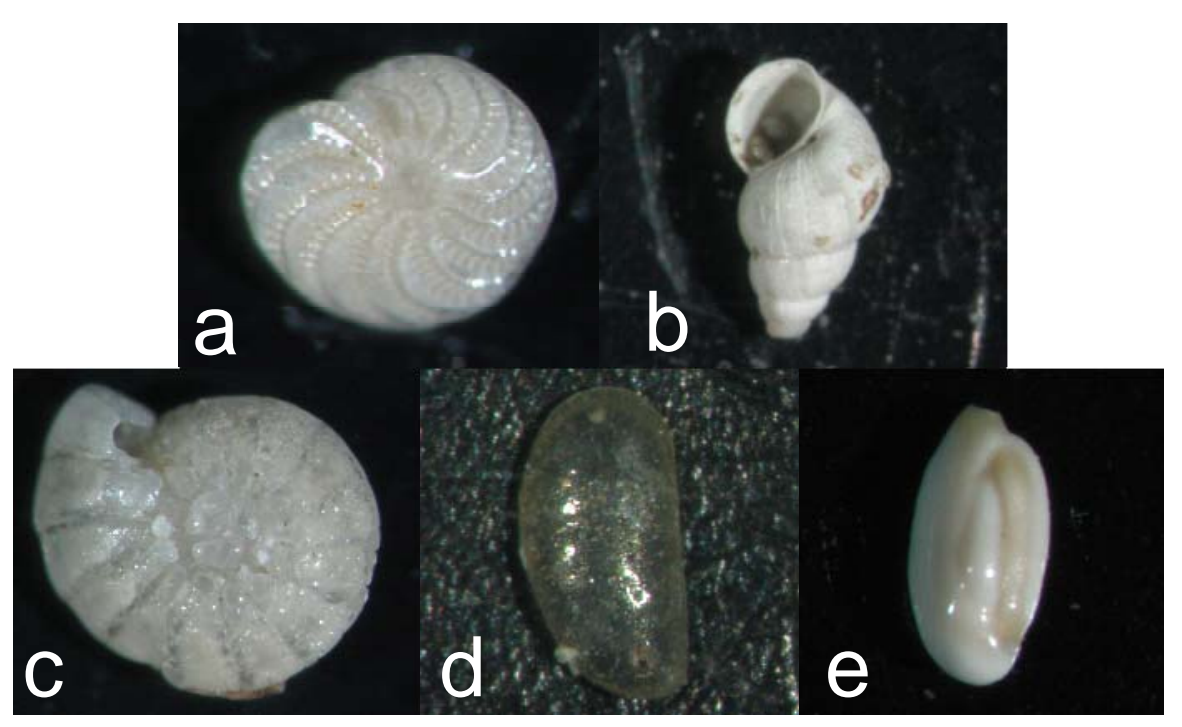

Holocene evolution

of Alikes lagoon

P. Avramidis and

N. Kontopoulos

\section{Title Page}

\begin{tabular}{|c|c|}
\hline Abstract & Introduction \\
\hline Conclusions & References \\
\hline Tables & Figures \\
\hline I & $\bullet$ \\
\hline 4 & $\bullet$ \\
\hline Back & Close \\
\hline Full Screen / Esc
\end{tabular}

Fig. 8. Representative fauna from the examined samples. (a) Elphidium crispum sa. M2, (b) Hydrobia ventrosa sa. M7, (c) Ammonia beccarii sa. 10, (d) Cyprideis torosa sa. M3 and (e) Quinqueloculina seminula sa.M7. 


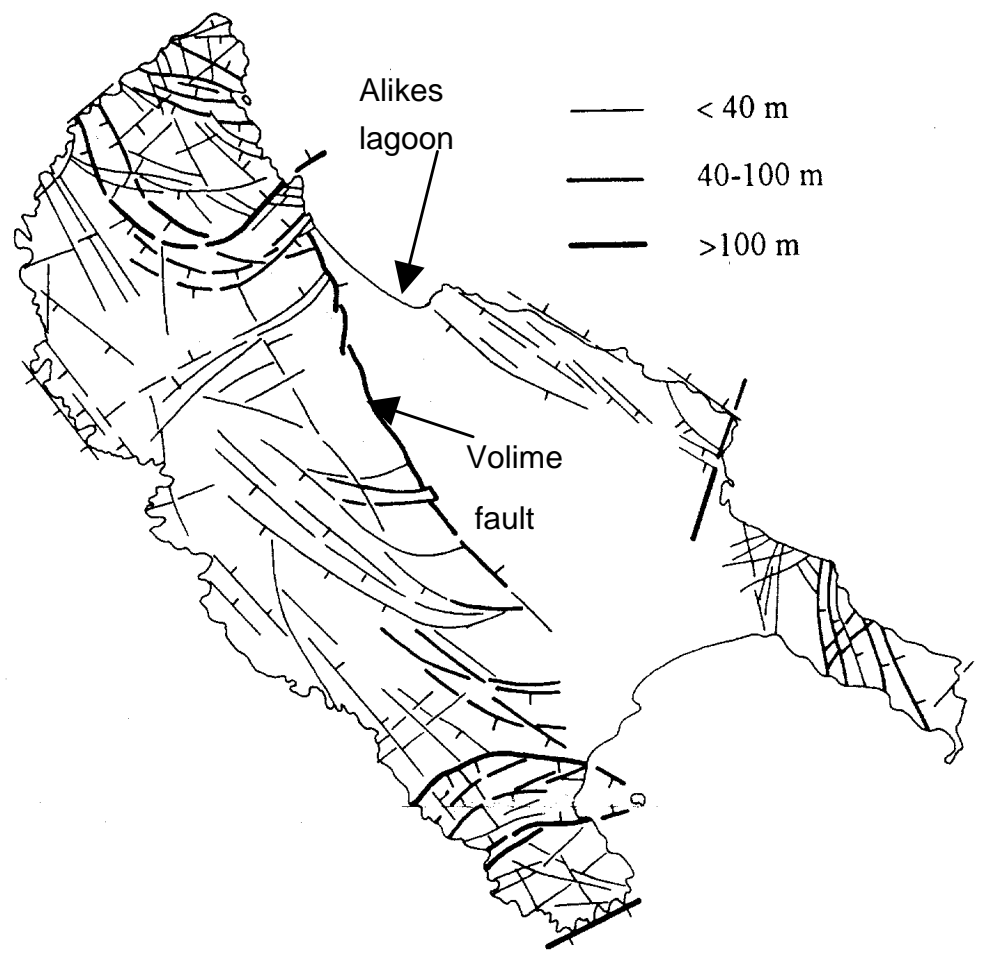

\section{Holocene evolution of Alikes lagoon \\ P. Avramidis and \\ N. Kontopoulos}

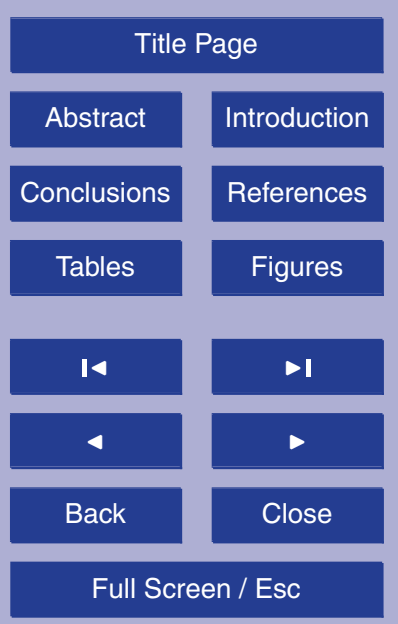

Fig. 9. Neotectonic map of Zakynthos island showing the vertical displacement for each fault and the location of Alikes lagoon and Volime fault (Lekkas, 1993).

Printer-friendly Version

Interactive Discussion 
4, 55-75, 2009

\section{Holocene evolution of Alikes lagoon}

P. Avramidis and

N. Kontopoulos

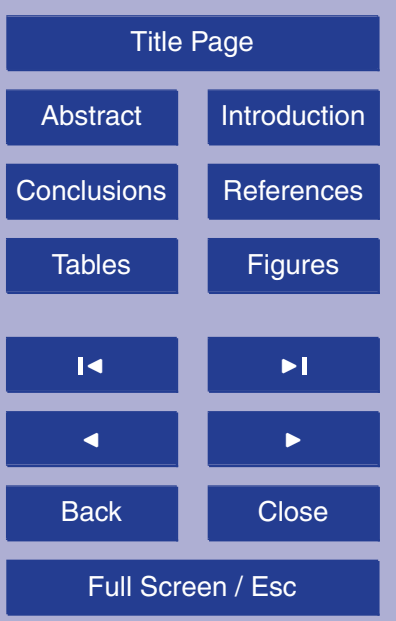

Printer-friendly Version

Interactive Discussion 